\title{
Relationship of Extent of Participation and Impact of National Watershed Development programme by the Beneficiaries
}

\author{
Miss K.U. Deshmukh ${ }^{1}$, Dr. R. P. Kadam², Dr. G.S. Pawar ${ }^{3}$ \\ ${ }^{1}$ Ph.D. Scholar, Extension Education Section, College of Agriculture, VNMKV, Parbhani, Maharashtra, India \\ ${ }^{2}$ Associate Professor, Extension Education Section, College of Agriculture, VNMKV, Parbhani, Maharashtra, India \\ ${ }^{3}$ ASRO, Extension Education Section, College of Agriculture, VNMKV, Parbhani, Maharashtra, India
}

\begin{abstract}
The present investigation was conducted in Beed and Nanded district of Marathwada region in Maharashtra State. The main objective of the study was to assess the relationship between profile of beneficiaries with their extent of participation and impact of NWDP. The data were collected with the help of pre-designed interview schedule by contacting 200 respondents i.e. 100 beneficiaries from watershed villages and 100 nonbeneficiaries from non-watershed villages. The result revealed that majority $(70.00 \%)$ of the beneficiaries having middle aged, followed by 38.00 per cent of the beneficiaries were educated up to secondary school level, while 52.00 per cent of the beneficiaries were having medium family size. Further it was observed that 53.00 per cent of the beneficiaries were from higher caste i.e. major castes - Maratha, Brahmin, while 49.00 per cent of the beneficiaries having semi medium land holding, whereas 60.00 per cent of the beneficiaries having medium area under irrigation. It was also found that 66.00 per cent of the beneficiaries having medium annual income, while 46.00 per cent of the beneficiaries having medium social participation, whereas 61.00 per cent of the beneficiaries having medium level of extension contact, and 52.00 per cent of the beneficiaries having medium level of economic motivation. Also the result showed that education, family size, land holding, area under irrigation, annual income, social participation, extension contact and economic motivation were found to be positively and significantly related with extent of participation and impact of NWDP.
\end{abstract}

Keywords-Extent of participation, Impact, Beneficiaries.

\section{INTRODUCTION}

The challenges before Indian agriculture is to transform rainfed farming into more sustainable and productive system by giving social, economical and technological backup to the people who depend upon it. Moreover, the economy is mainly dependent on stability of crop production in rainfed areas. The land, water, climate, flora and fauna are the basic resources for agricultural development, which are subjected to various processes leading to their deterioration, particularly in rainfed areas. Development of the dryland areas is, therefore, an inescapable necessity for increasing and stabilizing income, generating employment and to rise the living of standard of dryland farmers on one hand and ensuring 'equity' on the other. The soil conservation techniques aim at reducing short-term risk in crop production, while maintaining long term stability of production. Thus, the uplifting rainfed farmers from their pathetic condition through development of dry farming by improving soil and moisture conservation on watershed approach received gather attention. The present study was undertaken with the following specific objective

1. To study the profile of beneficiaries and nonbeneficiaries of NWDP.

2. To delineate relationship between profile of beneficiaries with their extent of participation and impact of NWDP

\section{METHODOLOGY}

The research study was carried out purposively in Beed and Nanded district of Marathwada region in Maharashtra State. From each district, two talukas were purposively selected based on the maximum treated area (in ha.) under NWDP. The study was conducted in 8 villages (4 watershed villages and 4 non-watershed villages) of Beed 
and Nanded district. Watershed villages were selected purposively based on the maximum treated area (in ha.) under NWDP. From each village 25 respondents were randomly selected to make 200 samples of respondents in total. All the respondents were personally interviewed at their home and farms and data was collected. The collected data was analyzed with the help of suitable statistical methods i.e. frequency, percentage, mean, standard deviation, coefficient of correlation, path analysis, multiple regression and Z-test.

\section{RESULTS AND DISCUSSION}

A) Profile of the beneficiaries and non-beneficiaries

Table.1: Profile of the beneficiaries and non-beneficiaries

\begin{tabular}{|c|c|c|c|c|c|}
\hline \multirow{2}{*}{$\begin{array}{l}\text { Sr. } \\
\text { No. }\end{array}$} & \multirow[t]{2}{*}{ Characteristics } & \multicolumn{2}{|c|}{ Watershed } & \multicolumn{2}{|c|}{ Non watershed } \\
\hline & & Frequency & $\%$ & Frequency & $\%$ \\
\hline \multirow[t]{4}{*}{1.} & Age & & & & \\
\hline & 1. Young age & 16 & 16 & 14 & 14 \\
\hline & 2. Middle age & 70 & 70 & 73 & 73 \\
\hline & 3. Old age & 14 & 14 & 13 & 13 \\
\hline \multirow[t]{6}{*}{2.} & Education & & & & \\
\hline & 1. Illiterate & 12 & 12 & 17 & 17 \\
\hline & 2. Primary school & 23 & 23 & 26 & 26 \\
\hline & 3. Secondary school & 38 & 38 & 36 & 36 \\
\hline & 4. Higher secondary & 20 & 20 & 16 & 16 \\
\hline & 5. Graduates & 07 & 07 & 05 & 05 \\
\hline \multirow[t]{4}{*}{3.} & Family size & & & & \\
\hline & 1. Big & 36 & 36 & 28 & 28 \\
\hline & 2. Medium & 52 & 52 & 47 & 47 \\
\hline & 3. Small & 12 & 12 & 25 & 25 \\
\hline \multirow[t]{4}{*}{4.} & Caste & & & & \\
\hline & 1. Higher (All major castes) & 53 & 53 & 48 & 48 \\
\hline & 2. Middle (Baniya, Marwadi, Muslim) & 10 & 10 & 19 & 19 \\
\hline & 3. Lower (SC, ST, NT, DNT etc.) & 37 & 37 & 33 & 33 \\
\hline \multirow[t]{6}{*}{5.} & Land holding & & & & \\
\hline & 1. Marginal & 08 & 08 & 47 & 47 \\
\hline & 2. Small & 30 & 30 & 40 & 40 \\
\hline & 3. Semi-medium & 49 & 49 & 10 & 10 \\
\hline & 4. Medium & 12 & 12 & 03 & 03 \\
\hline & 5. Big & 01 & 01 & 00 & 00 \\
\hline \multirow[t]{4}{*}{6.} & Area under irrigation & & & & \\
\hline & 1. Low & 15 & 15 & 77 & 77 \\
\hline & 2. Medium & 60 & 60 & 18 & 18 \\
\hline & 3. High & 25 & 25 & 05 & 05 \\
\hline \multirow[t]{4}{*}{7.} & Annual income & & & & \\
\hline & 1. Low & 24 & 24 & 20 & 20 \\
\hline & 2. Medium & 66 & 66 & 64 & 64 \\
\hline & 3. High & 10 & 10 & 16 & 16 \\
\hline \multirow[t]{4}{*}{8.} & Social participation & & & & \\
\hline & 1. Low & 19 & 19 & 48 & 48 \\
\hline & 2. Medium & 46 & 46 & 38 & 38 \\
\hline & 3. High & 35 & 35 & 14 & 14 \\
\hline
\end{tabular}




\begin{tabular}{|l|l|l|l|l|l|}
\hline 9. & Extension contact & & & & \\
\hline & 1. Low & 19 & 19 & 56 & 56 \\
\hline & 2. Medium & 61 & 61 & 27 & 27 \\
\hline & 3. High & 20 & 20 & 17 & 17 \\
\hline $\mathbf{1 0 .}$ & Economic motivation & & & & \\
\hline & 1. Low & 18 & 18 & 45 & 45 \\
\hline & 2. Medium & 52 & 52 & 32 & 32 \\
\hline & 3. High & 30 & 30 & 23 & 23 \\
\hline
\end{tabular}

It was found that majority $(70.00 \%)$ of the respondents from watershed villages and 73.00 per cent of respondents from non-watershed villages were middle aged, followed by38.00 per cent of the respondents from watershed villages and 36.00 per cent of respondents from non-watershed villages were educated up to secondary school level, while more than half $(52.00 \%)$ of the respondents from watershed villages and 47.00 per cent of respondents from non-watershed villages were having medium family size. Further it was observed that 53.00 per cent of the respondents from watershed villages and 48.00 per cent of respondents from non-watershed villages were from higher caste i.e. major castes Maratha, Brahmin. Nearly half $(49.00 \%)$ of the respondents from watershed villages having semi medium land holding, whereas 47.00 per cent of respondents from non-watershed villages having marginal land holding, whereas majority $(60.00 \%)$ of the respondents from watershed villages having medium area under irrigation, whereas 77.00 per cent of respondents from nonwatershed villages having low area under irrigation.

It was also found that 66.00 per cent of the respondents from watershed villages and 64.00 per cent of respondents from non-watershed villages were having medium annual income, while It was noticed that 46.00 per cent of the respondents from watershed villages having medium social participation whereas 48.00 per cent of respondents from non-watershed villages having low social participation. Majority $(61.00 \%)$ of the respondents from watershed villages having medium level of extension contact whereas 56.00 per cent of respondents from non-watershed villages having low extension contact and More than half $(52.00 \%)$ of the respondents from watershed villages having medium level of economic motivation whereas 45.00 per cent of respondents from non-watershed villages having low economic motivation.

\section{B) Relational analysis}

Table.2: Relationship between profile of beneficiaries with the extent of participation

\begin{tabular}{|c|l|c|}
\hline $\begin{array}{c}\text { Sr. } \\
\text { No. }\end{array}$ & \multicolumn{1}{|c|}{$\begin{array}{c}\text { Independent } \\
\text { variable }\end{array}$} & $\begin{array}{c}\text { Correlation } \\
\text { coefficient }\end{array}$ \\
\hline 1 & Age & $0.140 \mathrm{NS}$ \\
\hline 2 & Education & $0.789^{* *}$ \\
\hline 3 & Family size & $0.531^{* *}$ \\
\hline 4 & Caste & $0.137 \mathrm{NS}$ \\
\hline 5 & Land holding & $0.891^{* *}$ \\
\hline 6 & $\begin{array}{l}\text { Area under } \\
\text { irrigation }\end{array}$ & $0.852^{* *}$ \\
\hline 7 & Annual income & $0.584^{* *}$ \\
\hline 8 & Social participation & $0.825^{* *}$ \\
\hline 9 & Extension contact & $0.624^{* *}$ \\
\hline 10 & $\begin{array}{l}\text { Economic } \\
\text { motivation }\end{array}$ & $0.778^{* *}$ \\
\hline
\end{tabular}

** Significant at 0.01 per cent level of probability

The correlation analysis of profile of beneficiaries with their extent of participation and impact of NWDP were calculated and illustrated. Table 2 revealed that the independent variables viz., education, family size, land holding, area under irrigation, annual income, social participation, extension contact and economic motivation were found to be positively and significantly related with extent of participation. However age and caste could not establish any relationship with extent of participation. These findings are in line with the findings of Naberia and khare (2006), Jirli and Kumar (2010), Mendel and Mukhopadhey (2012), Singh et al. (2015) and Sharma and Badodiya (2016).

Table.3: Relationship between profile of beneficiaries with the impact of NWDP

\begin{tabular}{|c|l|c|}
\hline $\begin{array}{c}\text { Sr. } \\
\text { No. }\end{array}$ & Independent variable & $\begin{array}{c}\text { Correlation } \\
\text { coefficient }\end{array}$ \\
\hline 1 & Age & $-0.122 \mathrm{NS}$ \\
\hline 2 & Education & $0.685^{* *}$ \\
\hline 3 & Family size & $0.433^{* *}$ \\
\hline
\end{tabular}


ISSN: 2456-1878

\begin{tabular}{|c|l|c|}
\hline 4 & Caste & -0.099 NS \\
\hline 5 & Land holding & $0.794 * *$ \\
\hline 6 & Area under irrigation & $0.782^{* *}$ \\
\hline 7 & Annual income & $0.665^{* *}$ \\
\hline 8 & Social participation & $0.753 * *$ \\
\hline 9 & Extension contact & $0.524 * *$ \\
\hline 10 & Economic motivation & $0.677 * *$ \\
\hline
\end{tabular}

** Significant at 0.01 per cent level of probability

The result of correlation analysis evident from Table 3 that education, family size, land holding, area under irrigation, annual income, social participation, extension contact and economic motivation were found to be positively and significantly related with impact of NWDP. The other independent variables namely age and caste could not establish any relationship with impact of NWDP. These findings are in agreement with the findings of Ahire (2000), Erappa (2000), Bhange (2004), Nakhate (2006), Nipanikar (2006), Tayde (2011) and Sirohiya (2012).

\section{Multiple regression analysis}

Multiple regression analysis was calculated to know combine effect of all independent variables in explaining the dependent variables.

It is observed from Table 4 that co-efficient of determination $\left(\mathrm{R}^{2}\right)$ of the independent variables was 0.942. It means that selected ten independent variables explained 94.20 per cent variation in extent of participation. The value of ' $\mathrm{t}$ ' showed that education $(\mathrm{t}=$ 2.553), land holding $(\mathrm{t}=3.545)$, area under irrigation $(\mathrm{t}=$ $2.809)$, annual income $(\mathrm{t}=6.631)$ and social participation $(\mathrm{t}=4.479)$ were found to be positively and significantly in extent of participation. These variables therefore emerged as crucial variables in explaining the variation. Hence, these five variables were found most important variables in exercising influence on extent of participation of beneficiaries in NWDP.

Table.4: Multiple regression analysis of profile of beneficiaries with the extent of participation of beneficiaries in NWDP

\begin{tabular}{|c|l|c|c|c|}
\hline $\begin{array}{c}\text { Sr. } \\
\text { No. }\end{array}$ & $\begin{array}{c}\text { Independent } \\
\text { variable }\end{array}$ & $\begin{array}{c}\text { Regression } \\
\text { co-efficient }\end{array}$ & SE(bi) & $\begin{array}{c}\text { 't' } \\
\text { value }\end{array}$ \\
\hline 1 & Age & 0.074 & 0.048 & 1.520 \\
\hline 2 & Education & 1.252 & 0.490 & $2.553^{*}$ \\
\hline 3 & Caste & -0.194 & -0.220 & -0.881 \\
\hline 4 & Family size & -2.380 & 0.561 & -4.239 \\
\hline 5 & Land holding & 2.616 & 0.737 & $3.545^{* *}$ \\
\hline
\end{tabular}

\begin{tabular}{|c|l|c|c|c|}
\hline 6 & $\begin{array}{l}\text { Area under } \\
\text { irrigation }\end{array}$ & 3.446 & 1.226 & $2.809^{* *}$ \\
\hline 7 & $\begin{array}{l}\text { Annual } \\
\text { income }\end{array}$ & 0.053 & 0.008 & $6.631^{* *}$ \\
\hline 8 & $\begin{array}{l}\text { Social } \\
\text { participation }\end{array}$ & 3.359 & 0.749 & $4.479^{* *}$ \\
\hline 9 & $\begin{array}{l}\text { Extension } \\
\text { contact }\end{array}$ & 0.188 & 0.169 & 1.108 \\
\hline 10 & $\begin{array}{l}\text { Economic } \\
\text { motivation }\end{array}$ & -0.773 & 0.249 & -3.102 \\
\hline
\end{tabular}

$\mathrm{R} 2=0.942$

$\mathrm{F}=1.442$

*Significant at 0.05 level of probability ** Significant at 0.01 level of probability

It is seen from Table 5 that co-efficient of determination $\left(\mathrm{R}^{2}\right)$ of the independent variables was 0.895 . It means that selected ten independent variables explained 89.50 per cent variation in extent of participation.

Table.5: Multiple regression analysis of profile of beneficiaries with impact of NWDP

\begin{tabular}{|c|l|c|c|c|}
\hline $\begin{array}{c}\text { Sr. } \\
\text { No. }\end{array}$ & $\begin{array}{l}\text { Independent } \\
\text { variable }\end{array}$ & $\begin{array}{c}\text { Regression } \\
\text { co-efficient }\end{array}$ & SE(bi) & $\begin{array}{c}\text { 't' } \\
\text { value }\end{array}$ \\
\hline 1 & Age & -6.934 & 3.992 & -1.736 \\
\hline 2 & Education & 18.712 & 38.944 & 0.480 \\
\hline 3 & Caste & -15.735 & 15.481 & -1.016 \\
\hline 4 & Family size & -134.42 & 45.278 & -2.968 \\
\hline 5 & Land holding & 183.41 & 59.268 & $3.094^{* *}$ \\
\hline 6 & $\begin{array}{l}\text { Area under } \\
\text { irrigation }\end{array}$ & 352.18 & 102.47 & $3.436^{* *}$ \\
\hline 7 & $\begin{array}{l}\text { Annual } \\
\text { income }\end{array}$ & 3.647 & 0.648 & $5.624^{* *}$ \\
\hline 8 & $\begin{array}{l}\text { Social } \\
\text { participation }\end{array}$ & 207.16 & 60.302 & $3.435^{* *}$ \\
\hline 9 & $\begin{array}{l}\text { Extension } \\
\text { contact }\end{array}$ & 14.369 & 13.777 & 1.042 \\
\hline 10 & $\begin{array}{l}\text { Economic } \\
\text { motivation }\end{array}$ & -97.351 & 20.228 & -4.812 \\
\hline
\end{tabular}

$\begin{array}{ll}\mathrm{R} 2=0.895 & \mathrm{~F}=7.549\end{array}$

** Significant at 0.01 level of probability

The value of ' $t$ ' showed that impact was significantly related with land holding $(\mathrm{t}=3.094)$, area under irrigation $(\mathrm{t}=3.436)$, annual income $(\mathrm{t}=5.624)$ and social participation $(\mathrm{t}=3.435)$. These variables therefore emerged as crucial variables in explaining the variation. Hence, these four variables were found most important variables in exercising influence on impact of NWDP of beneficiaries. 


\section{CONCLUSIONS}

It is concluded that majority $(70.00 \%)$ of the beneficiaries having middle aged, followed by 38.00 per cent of the beneficiaries were educated up to secondary school level, while 52.00 per cent of the beneficiaries were having medium family size. Further it was observed that 53.00 per cent of the beneficiaries were from higher caste i.e. major castes - Maratha, Brahmin, while 49.00 per cent of the beneficiaries having semi medium land holding, whereas 60.00 per cent of the beneficiaries having medium area under irrigation. It was also found that 66.00 per cent of the beneficiaries having medium annual income, while 46.00 per cent of the beneficiaries having medium social participation, whereas 61.00 per cent of the beneficiaries having medium level of extension contact, and 52.00 per cent of the beneficiaries having medium level of economic motivation. Also education, family size, land holding, area under irrigation, annual income, social participation, extension contact and economic motivation were found to be positively and significantly related with extent of participation and impact of NWDP. While age and caste could not establish any relationship with extent of participation and impact of NWDP. Multiple regression analysis indicated that from all selected ten variables, five variables namely education, land holding, area under irrigation, annual income and social participation were significantly contributing factors in case of extent of participation and impact of NWDP.

\section{REFERENCES}

[1] Ahire, R.D. 2000. A Study on the Consequences of Watershed Development Programme. Ph. D. Thesis, Marathwada Agriculture University, Parbhani.

[2] Bhange, S.B. 2004. Impact of National Watershed Development Programme for Rainfed Areas on Socio-Economic Status of Farmers of Ahmednagar Distict. Ph.D. (Agri.) Thesis, Mahatma Phule Krishi Vidyapeeth, Rahuri.

[3] Erappa, S. 2000. Rapid Impact Evaluation of National Watershed Development Programme for Rainfed Areas (NWDPRA) Riachur District. Karnataka Agricultural Science Digest, 22(3): 7375.

[4] Jirli, B. and P. Kumar 2010. Peoples' Participation for Effective Management of Watershed Development Programme. Journal of Community Mobilization and Sustainable Development, 5(1):013-017.
[5] Mendel, W.M. and S.D. Mukhopadhey. 2012. Nature and Extent of Participation of Farm Women and their Economic Contribution in Agriculture - A Case Study in Hilly District of West Bengal. Indian Research Journal Extension Education, 12 (2): 6.

[6] Naberia, S. and N. Khare (2006). Role of Tribal Women in Watershed Development Programme. Indian Research Journal of Extension Education, 6 (3).

[7] Nakhate, S.S. 2006. Impact of Self Help Group on Socio-Economic Development of its Member. M.Sc. (Agri.), Thesis, Marathwada Agriculture University, Parbhani.

[8] Nipanikar, S.S. 2006. Impact of Watershed Development Programme on Beneficiaries in Osmanabad District. M.Sc. (Agri.) Thesis, Marathwada Agriculture University, Parbhani.

[9] Sharma, P. and S.K. Badodiya. 2016. Impact of Participation of Rural Women in Agriculture Activities. Indian Research Journal of Extension Education, 16 (2):12-14.

[10] Singh, S., S. Kushwah, V.B. Singh and O.P. Daipuria. 2015. Factor Affecting the Participation of Rural Women in Agricultural Activities. Indian Research Journal Extension Education, 15 (1):8183.

[11] Sirohiya, L., D.K. Singh and S.K.Agrawal. 2012. Impact of Trainings on Adoption of Chickpea (Cicer arietinum L.) Production Technology. Indian Journal of Extension Education, 48 (3 \& 4):87-89.

[12] Tayde, A.V. 2011. Impact of Watershed Development Programme on its Beneficiaries. M.Sc. (Agri.) Thesis, Panjabrao Deshmukh Krishi Vidyapeeth, Akola. 